\title{
Arsenic Induced Free Radicals Mediated Genotoxicity and Protective Features of Ocimum Gratissium L.
}

Nikhil Mishra

Government VYTPG Autonomous College Durg

Seema Tripathi

Department of Science and Technology

ANIL KUMAR ( $\sim$ anilkumardurg1996@gmail.com )

Government VYTPG Autonomous College Durg https://orcid.org/0000-0002-1667-4419

\section{Research Article}

Keywords: Arsenic, Comet assay, Lymphocytes, Oxidative Stress, Phytochemicals, Oryctolagus cuniculus

L. Ocimum gratissium L.

Posted Date: July 19th, 2021

DOl: https://doi.org/10.21203/rs.3.rs-679469/v1

License: (c) (i) This work is licensed under a Creative Commons Attribution 4.0 International License. Read Full License 


\section{Abstract}

Arsenic toxicity is a worldwide geogenic problem for large number of populations. The major problem of arsenicosis is generation of free radicals and related genotoxicity, In the present study three plants species Ocimum gratissimum L., Ocimum sanctum, Ocimum basilicum, were examined by both in vivo and in vitro methods in Oryctolagus cuniculus $L$ to know the free radical scavenging property in Sodium Arsenite induced oxidative stress and related genotoxicity. Oxidative stress was evaluated considering MDA, GSH, SOD, CAT \& GPx, and genotoxicity was examined by comet assay and RAPD test. In the present study, $\mathrm{Na}_{3} \mathrm{AsO}_{3}$ was found to generate free radicals in lymphocytes of $O$. cuniculus and best recovery was reported (MDA-4.78 \pm 0.05 ; GSH-2.87 $\pm 0.50 ;$ SOD-1.78 $\pm 0.03 ; \mathrm{CAT}-2.72 \pm 0.02 ; \mathrm{GPX}-7.43 \pm$ 0.01) under exposure of ethanolic leaf extract of 0 . gratissimum. $\mathrm{Na}_{3} \mathrm{AsO}_{3}$ was also found to cause polymorphic bands and increased comet tail in lymphocytes which was found significantly recovered by exposure of ethanolic leaf extract of 0 . gratissimum.

\section{Introduction}

Arsenic (As) has been well recognized as an element of grave concern for the people. In contrast to several other potentially toxic elements, local health effects are apparent in areas naturally enriched with arsenic as well as in areas contaminated by industrial activities. This element has been quite extensively studied in terrestrial environments, fresh and marine waters and air in some geographic regions. According to WHO, 2011, except for those individuals who are occupationally exposed to arsenic, the most important route of Arsenic exposure is through the oral intake of food and drinking-water, including beverages made from drinking-water. The mean daily intake of arsenic from drinking-water under normal conditions is generally less than $10 \mu \mathrm{g}$, but in those areas in which natural underground drinking-water contains elevated concentrations of arsenic, will make an increasingly significant contribution to the total intake of inorganic arsenic, as the concentration of arsenic in drinking-water increases.

In Indian subcontinent, Bengal delta plain (Islam et al.2004) and Gangetic plains of Uttar Pradesh and Bihar states (Chakarborti et al. 2003, 2004) underground arsenic contamination has been a established fact now, besides, in Chhattisgarh underground water contamination in Ambagarh Chowki of Rajnandgaon district has also been reported (Pandey et al. 1999) and in all the reported area it was found above the permissible limits of WHO i.e., 10 $\mathrm{g} / \mathrm{L}$ (WHO 2001). Individuals that are chronically exposed to Arsenic are at elevated risk of suffering from various serious ailments such as cancers, skin diseases, ischemic heart diseases, neurological problems and teratogenicity (Gambell et al. 2005). Arsenite (As III) generally found in deep wells with anaerobic conditions, cannot be oxidized by aerobic bacteria to As (V) (Inskeep et al. 2007), and it is potentially less mobile in the subsurface environment (ASTDR 2005), therefore it is (As III, less mobile) considered to be most potent environmental carcinogen. As III, has been reported to induce genetic alterations like chromosomal aberrations, micronuclei formation, gene amplification and known to block DNA repair (Vogt and Rossman 2001). Environmental activity of Arsenic may produce free radicals mainly in the form of hydroxyl $(\mathrm{OH})$ and Superoxide radicals (Hei, Liu and Wldren 1998). Among the various modes of action for Arsenic related carcinogenesis, the oxidative 
stress mediated through reactive oxygen species (ROS) can directly or indirectly damage DNA, lipids and proteins (Liu et al. 2001; Kitchin and Ahmad 2003; Manna, Sinha and Sil 2008). Genetic abnormalities without effective DNA repairs, leads to mutation and ultimately leads to carcinogenesis. The carcinogenicity of arsenite compounds (As III) is partly based upon the fact that its mutagenic activity resides on the ROS (Shi, Shi and Liu 2004). ROS creates oxidative stress by targeting macromolecules like proteins, structural carbohydrates, lipids and DNA which are the primary electron rich sites within the cells (Romero et al. 1998).

Physiologically speaking about $5 \%$ or more of inhaled Oxygen $\left(\mathrm{O}_{2}\right)$ is converted to ROS such as $\mathrm{O}_{2}{ }^{-}$, $\mathrm{H}_{2} \mathrm{O}_{2}$, and OHby univalent reduction of $\mathrm{O}_{2}$ (Maxwell 1995). Antioxidants act as scavengers of ROS (SOD removing $\mathrm{O}_{2}^{-}$) by inhibiting their formation in several ways (Niwa et al. 2001).

According to the Indian traditional system of medicines like Ayurveda, some rasayanas (group of nontoxic poly herbal drug preparations) and various plants with well-defined antioxidant properties of which many of them are also immunostimulatory and can prevent the cause of disease and promote health and longevity (Scartezzini and Speroni 2000; Rekha, Kuttan and Kuttan 2001).

Some species of Lamiaceaefamily especially Ocimum species are traditionally well known for their medicinal values and used for the treatment of various diseases such as upper respiratory tract infections, diarrhea, headache, ophthalmic, skin diseases, pneumonia, cough fever, conjunctivitis, tooth and gum disorders etc. (Onajobi 1986; Okigbo and Ogbonnanya 2006).

In the present study Phytochemical investigation of three species of Ocimum genus viz.,Ocimum gratissimum, Ocimum sanctum and Ocimum basilicum was performed and on the basis of phytoconsituents, Ocimum gratisimum L. was used as plant of choice for the study of its ameliorative effect on Sodium arsenite $\left(\mathrm{Na}_{3} \mathrm{AsO}_{3}\right)$ induced oxidative stress and related genotoxicity in peripheral blood lymphocyte of Oyctolagus cuniculus $\mathrm{L}$.

\section{Materials And Methods}

In the present study, $\mathrm{Na}_{3} \mathrm{AsO}_{3}$ induced oxidative stress and genotoxicity was evaluated in Oryctolagus cuniculus $L$ (Rabbit) and phytoremediation was examined by Ocimum species. Three species, Ocimum gratissimum, Ocimum sanctum and Ocimum basilicum were collected from from sandy alluvial soil deposits in rock- cervices from Chitrakote waterfall of Jagdalpur (Bastar district; $19.2072^{\circ} \mathrm{N}, 81.7001^{\circ} \mathrm{E}$ ), Chhattisgarh, India, fresh leaves were washed, shade dried, grinded and subjected to soxhlet extraction. Phytochemical analyses of leaves of all three plants were carried out in Ethanol and Chloroform (Trease and Evans 1985; Harborne and Williams 2000; Sofowora 1993; Brindha, Sasikala and Purushothaman 1981).

As a test animals, Oryctolagus cuniculus L (Rabbit) of 8-10 weeks old, weight 1.25 to $2 \mathrm{~kg}$ were maintained in Laboratory following approval of Institutional Ethics Committee (Ref. 
No.IEC/GVYTPGAC/02/DURG, dated 28/09/2012) .

For in vitro examination of antioxidant property of plants, blood was collected from the pinna of Oryctolagus cuniculus, lymphocytes were separated by HiPrep Lymhocyte separation Kit (Himedia, Mumbai) and cultured in Dulbecco's modified Eagle's Media (DMEM) along with $10 \%$ fetal calf serum in a humified $\mathrm{CO} 2$ incubator at $37^{\circ} \mathrm{C}$ and $5 \% \mathrm{CO} 2$ for 18 to 24 hours. Cell cultures were diluted with Phosphate buffer saline and used for study.

In experimental process three sets were prepared, Set I - with only lymphocytes; Set II - with Lymphocytes $+100 \mu \mathrm{M} \mathrm{H}_{2} \mathrm{O}_{2}$ exposure for 3 hours; Set III- with $100 \mu \mathrm{M} \mathrm{H}_{2} \mathrm{O}_{2}$ treated lymphocytes and $10 \mu \mathrm{M}$ extracts of plants.

For determination of antioxidant property of plant extracts, Lipid peroxidase/ Malondialdehyde (MDA) (Ohkawa, Ohishi and Yagi 1979), Reduced glutathione (GSH) (Moron, Depierre and Mannervik 1979), Superoxide dismutase (SOD) (Misra and Fridovich 1972), Catalase (CAT) (Bergmeyer, Gowehu and Grassel 1974) and Glutathione peroxidase (GPx) (Rotruck et al. 1973) were evaluated from all three sets, besides a parallel control set was also maintained.

By above experiment, Ethanolic extract of Ocimum gratissimum was found to possess best antioxidant property, so with this extract in vivo experiment was performed on $O$. cuniculus under influence of sodium arsenite $\left(\mathrm{Na}_{3} \mathrm{AsO}_{3}\right)$.

In order to assess the Arsenic induced oxidative stress in test animals $O$. cuniculus $L$, as a test chemical, a $1 \%$ solution of sodium arsenite $\left(\mathrm{NaAsO}_{2}\right)$ was administered orally $(0.25 \mathrm{mg} / \mathrm{Kg}$. bw.) to the test animal for six months after interval of 7 days each, following the method given by Preston et al. 1987. After chronic exposure (6 months) of the test chemical, blood was collected from the pinna of rabbit and lymphocytes were separated as previously described and again oxidative stress was measured (MDA, GSH, SOD, CAT, \& GPx) as before. All experimental sets were maintained in replicates of five test animals along with parallel control set.

Genotoxicity was evaluated following comet assay (Singh et al. 1988) and RAPD-PCR (Williams et al. 1990) from $\mathrm{Na}_{3} \mathrm{AsO}_{3}$ intoxicated lymphocyte cells of $O$. cuniculus(50 cells). The comet tail length was determined as pixels ( 45 pixels $=1$ unit) and observation was made using $40 x$ objective on a fluorescent microscope, (Olympus Microscope-CX21i with Y-FL EPI-Fluorescence attachment; excitation filter of 515-560 nm \& barrier filter 590nm) and tail length were measured using ImageJ (National Institute of Health, USA).

Beside Comet assay, RAPD was also performed to know the genetic variation due to arsenic induced oxidative stress using random operon primers. For this extraction of DNA from blood of the test animals was carried out with the help of Genei KT 163 whole blood genome isolation kit, followed by quantification of DNA and purification. Dilution of DNA sample was done $(2.5 \mathrm{mg} / \mu \mathrm{l})$ for RAPD analysis. PCR amplification [30 $\mu$ l reaction mixture containing $3 \mu$ l of $10 x$ enzyme buffer, $3 \mu l$ of $2 \mu \mathrm{M}$ dNTP, $2 \mu \mathrm{l}$ of 
pmol of 6 random operon primers (Table-2), 1-5 U of Taq DNA polymerase and $25 \mu \mathrm{g}$ of DNA as template] was performed. PCR conditions were maintained as Denaturing of $94^{\circ} \mathrm{C}$ for $0.5 \mathrm{~min}$., annealing at $40^{\circ} \mathrm{C}$ for $1 \mathrm{~min}$., extension at $72^{\circ} \mathrm{C}$ for $1 \mathrm{~min}$. followed by electrophoresis of PCR products $(20 \mu \mathrm{l}$ each PCR products, was mixed with loading buffer and loaded in $2 \%$ agarose gel, then electrophoresed at $100 \mathrm{~V}$ for $70 \mathrm{~min}$.). Gel was stained with ethidium bromide $(0.5 \mu \mathrm{g} / \mathrm{ml})$ and then visualized in UV under gel documentation system (Lark).

For phytoremediation study, $2 \mathrm{ml}$ of the extract was orally administered to the same sodium arsenite exposed rabbits for a period of 1 month continuously. Again, blood was collected from pinna, lymphocytes were separated and oxidative stress was measured considering same enzymatic parameters. Comet assay and RAPD was also again performed from the blood of same rabbits as described before for comparative finding.

\section{Results}

\section{In vitro study}

Phytochemical analysis of leaf extracts of all three species of Ocimum resulted presence of Cardiac glycoside, Steroids, Flavonoids, Saponins, Tannins, Terpenoids and Alkaloids as shown (Table -1) and maximum number of major phytochemical group was reported from 0 . gratissimum $\mathrm{L}$.

The comparative analysis of in vitro antioxidant activities of all the three plants on the cultured lymphocytes of $O$. cuniculus in terms of assessment of antioxidant enzymatic parameters (MDA, GSH SOD, CAT \& GPx) in all three set of test animals revealed that the ethanolic extract of Ocimum sanctum $\mathrm{L}$. (Leaf) and Ocimum gratissimum L. (Leaf)were found topossessbetter antioxidant property than chloroform extracts, whereas Ocimum basilicumL. (Leaf) showed better result in chloroform extract.It was also estimated that among all the three plants, ethanol extract of leaf of Ocimum gratissimum $\mathrm{L}$. exhibited highest antioxidant property in set III test samples containing plant extract along with $\mathrm{H}_{2} \mathrm{O}_{2}$ $[\mathrm{MDA}(3.60 \pm 0.02), \mathrm{GSH}(3.42 \pm 0.03)$, SOD $(1.82 \pm 0.01)$, CAT $(3.18 \pm 0.02) \&$ GPx (7.68 \pm 0.06$)]$ and thus selected for further study (Figure 1, $2 \& 3$ ).

\section{In vivo study}

We found that, Malondialdehyde(MDA) activity (nmole MDA/mg protein) was increased by $4.78 \pm$ 0.33after chronic exposure of $\mathrm{Na}_{3} \mathrm{AsO}_{3}$ compared to control $(0.78 \pm 0.0262)$ and after treatment with leaf extract of 0 . gratissimum, it was found reduced to $1.02 \pm 0.105[\mathrm{t}=12.68>2.776$ @ $5 \% \mathrm{P}$ and $95 \% \mathrm{Cl}$ with mean difference of 3.12 and 4.87] while comparing Arsenic treated samples with control; $t=2.50<2.776$ @ 5\% $\mathrm{P}$ and $95 \% \mathrm{Cl}$ with mean difference of 0.50 and 0.026 ] while comparing plant extract treated samples with control; $[\mathrm{t}=14.22>2.776 @ 5 \% \mathrm{P}$ and $95 \% \mathrm{Cl}$ with mean difference of 3.02 and 4.49$]$ while comparing between arsenic treated and plant extract treated samples](Figure 4). Thus the results showed a significant amelioration from oxidative stress by treating the lymphocytes (chronically exposed with sodium arsenite) with the ethanol extract of leaf of 0 . gratissimum in terms of MDA. 
Whereas other parameters like reduced glutathione [GSH ( $\mu$ moles $/ \mathrm{mg}$ proteins)] found decreased in arsenic treated samples by $2.87 \pm 0.019$ as compared to control $(5.50 \pm 0.163)[\mathrm{t}=17.02>2.776 @ 5 \% \mathrm{P}$ and $95 \% \mathrm{Cl}$ with mean difference of 2.20 and 3.05]. But it was found increased by $5.98 \pm 0.059$ [ $\mathrm{t}=3.52>$ $2.776 @ 5 \% \mathrm{P}$ and $95 \% \mathrm{Cl}$ with mean difference of 0.05 and 0.101$]$ when chronically exposed 0 . cuniculus are again orally treated with ethanol leaf extract of Ocimum gratissimum and compared with control subjects. Further when compared the results between arsenic treated and plant extract treated samples we found that plant extract has a significantly positive impact on GSH activity [t=56.97>2.776 @ 5\%P and $95 \% \mathrm{Cl}$ with mean difference of 3.26 and 2.59]; Superoxide dismutase (SOD) activity (Units/mg protein) was also found significantly decreased by $1.78 \pm 0.038$ in arsenic treated samples as compared to control set $(3.75 \pm 0.031)$ [ $\mathrm{t}=66.03>2.776 @ 5 \% \mathrm{P}$ and $95 \% \mathrm{Cl}$ with mean difference of 1.88 and 2.05]. But it was found increased by $3.34 \pm 0.037[\mathrm{t}=10.66>2.776 @ 5 \% \mathrm{P}$ and $95 \% \mathrm{Cl}$ with mean difference of 0.30 and 0.51] in plant extract treated samples. Further when compared the results between arsenic treated and plant extract treated samples we found that that ethanol leaf extract of Ocimum gratissimum has a significantly positive impact on SOD activity $[\mathrm{t}=58.55>2.776 @ 5 \% \mathrm{P}$ and $95 \% \mathrm{Cl}$ with mean difference of 1.63 and 1.48];Catalase [CAT ( $\mu$ moles of $\mathrm{H}_{2} \mathrm{O}_{2}$ consumed / $\mathrm{min} / \mathrm{mg}$ proteins)] activity was also found decreased by $2.72 \pm 0.018$ in arsenic exposed subjects as compared to control set of test animals $(5.20 \pm 0.017)[\mathrm{t}=98.03>2.776 @ 5 \% \mathrm{P}$ and $95 \% \mathrm{Cl}$ with mean difference of 2.40 and 2.55$]$. But it was found again increased by $4.75 \pm 0.021[\mathrm{t}=19.19>2.776 @ 5 \% \mathrm{P}$ and $95 \% \mathrm{Cl}$ with mean difference of 0.38 and 0.51 ] in 0 . gratissimum leaf extract treated test animals. Further when compared the results between arsenic treated and plant extract treated samples we found that that ethanol leaf extract of 0 . gratissimum has a significantly positive impact on CAT activity $[\mathrm{t}=74.13>2.776$ @ 5\% P and $95 \% \mathrm{Cl}$ with mean difference of 2.10 and 1.95]; Glutathione peroxidase [GPx ( $\mu \mathrm{g}$ of glutathione utilised/ $\mathrm{min} / \mathrm{mg}$ protein)] activitywas also reported decreased significantly by $7.43 \pm 0.308$ in arsenic exposed test animals as compared to control set $(13.95 \pm 0.035)$ [ $t=234.96>2.776$ @ 5\% P and 95\% Cl with mean difference of 6.44 and 6.59 respectively]. But after oral treatment in same set of test samples with ethanol leaf extract of Ocimum gratissimum, the GPx activity was again found increased by $12.72 \pm$ $0.045[\mathrm{t}=30.37>2.776 @ 5 \% \mathrm{P}$ and $95 \% \mathrm{Cl}$ with mean difference of 1.11 and 1.34 respectively]. Further when compared the results between arsenic treated and plant extract treated samples, we found that ethanol leaf extract of 0 . gratissimum has a significantly positive impact on GPx activity $[\mathrm{t}=90.59>2.776$ @ 5\% P and $95 \% \mathrm{Cl}$ with mean difference of 5.45 and 5.12 respectively]. The result indicated a significant ameliorative effect of the plant extract (Figure 4).

The analysis of DNA damage by Comet assay on same set of test samples after chronic exposure of sodium arsenite exhibited a decrease in head DNA\% and tail moment while there was an increase in comet tail DNA\% and tail length as compared to control set (Figure 5) was observed (Figure 6. a-3months exposure: meanhead $D N A \%=83.44 \pm 1.45, t=11.20>2.776$; meantail $D N A \%=16.95 \pm 1.19, t=13.95>2.776$; meantail length $=8.2 \pm 0.58, \mathrm{t}=8.66>2.776$; meantail moment $=1.41 \pm 0.19, \mathrm{t}=7.33>2.776 @ 5 \% \mathrm{P} \& 95 \% \mathrm{Cl}$ and $b-6$ months exposure: meanhead DNA\% $=67.47 \pm 6.55, t=4.93>2.776$; meantail DNA\% $=32.52 \pm 6.55$, $\mathrm{t}=4.93>2.776$; meantail length $=30.4 \pm 2.54, \mathrm{t}=10.86>2.776$; meantail moment $=10.32 \pm 2.78, \mathrm{t}=3.70>2.776$ ) (Figure 5). But after 1 month treatment of leaf extract of 0 . gratissimum L.,there was significant increase 
in head DNA\% and tail moment, while there is a significant reduction in tail DNA\% and comet tail length (meanhead DNA\%=87.86 $\pm 1.58, t=7.49>2.776$; meantail $D N A \%=12.13 \pm 1.58, t=7.49>2.776$; meantail length=8.2 $\pm 1.46, \mathrm{t}=3.73>2.776$; meantail moment=1.07 $\pm 0.27, \mathrm{t}=3.85>2.776 @ 5 \% \mathrm{P}$ and $95 \% \mathrm{Cl}$ ) indicated recovery from $\mathrm{Na}_{3} \mathrm{AsO}_{3}$ induced DNA damage by 0 . gratissimum ethanolic leaf extract(Figure 7 and 8 ).

In PCR-RAPD analysis, 6 random decamer primers were used for the study of DNA damage which gave clear and reproducible polymorphic bands indicating DNA damage due to chronic exposure of Sodium arsenite and its recovery by alcoholic leaf extract of 0 . gratissimum $L^{\prime}$. A significant difference in the banding pattern of Sodium arsenite and leaf extract exposed samples were observed with respect to the control set. An average of 3.0 bands per primer was scored in the control set (Table 2; Figure9). RAPD analysis generated polymorphism was represented as the appearanceand/or loss of DNA fragments in treated (sodium arsenite and ethanolic extract of the plant) samples compared to the control set.In response to chronic exposure of Sodium Arsenite, maximum 10 bands were observed with primer OPA 01, followed by OPA03 \& OPC05 ( 9 and 6 bands each), with primers OPA04 and OPA07 ( 6 and 5 bands each) and a minimum of 3 bands were observed with OPC04 primer (Fig.10; Table 2) showing extent of DNA damage in 0 . cuniculus (the size of bands appearing were found variable with respect to base pair size). The average number of bands scored in the sodium arsenite treated samples was found 6.5.On the other hand, after treatment with ethanolic leaf extract of 0 . gratissimum L., theaverage number of polymorphic bands was found 3.16 and number of polymorphic bands were found reduced (OPA01 - 4 bands; OPA03 -3 bands; OPC05- 4 bands; OPA04 - 4 bands; OPA07- 2 bands; OPC0 $4-2$ band) when electrophoresis was performed following RAPD-PCR with same set of primers (Fig.11; Table 2). The reductions in number of polymorphic bands after treatment with leaf extract of the plant, and almost reduced number of bands up to similar extent appeared in both control and 0 . gratissimum extract treated set of animal samples with some differences in appearance as in case of OPA04 primer and disappearance of bands in 0 . gratissimum treated sets in case of OPA01 primer as compared to the control, proved recovery of damaged DNA.

\section{Discussion}

Formation of reactive oxygen species in any organism due to exposure of heavy metal like arsenic can cause damage to DNA, carbohydrate and protein which causes various diseases (Corsini et al. 1999; Santra et al. 2007). In the present study, variations in the activities of antioxidant enzymes were observedfollowing chronic exposure of sodium arsenite to O.cuniculus, and the activities were found restored to normal after treatment of ethanolic leaf extract of 0 . gratissimum $\mathrm{L}$.

Presence of principal phytoconstituents like alkaloids, glycosides, tannins, phenolic compounds, saponin, flavonoids, terpenoids, steroids, sterols, saponins, flavones and flavonoids from aqueous and alcoholic leaf extracts of $O$. gratissimum L.has been previously reported (Anjorin and Ugwu 2011; Choudhury et al. 2011). The antioxidant property of 0 . gratissimumwas reported and co-related with its phytochemical constituents previously (Sulistiarini 1999; Dubey, Tiwari and Mandin 2000; Holets et al. 2003). 
The methanolic and aqueous extracts of 0 . gratissimum have already shown to possess more DPPH scavenging activity and also a reductive potential comparable with those of gallic acid and ascorbic acid (Akinmoladun et al. 2007; Awah and Verla 2010). Obioma et al. 2011, determined better antioxidant properties of ethanol extract of the leaves of 0 . gratissimum using rat liver homogenate and found a significant inhibition at different concentration with nitric oxides, ferrous sulphate and carbon tetrachloride induced lipid peroxidation activities in comparison to ascorbic acid. A similar result with Adantium capillus veneris leaf extract in $\mathrm{H}_{2} \mathrm{O}_{2}$ induced oxidative stress in human peripheral blood lymphocyte was observed by Kumar (Kumar 2009).

Many phenolic compounds, like phenolic acids, and phenolic diterpenes and flavonoids, have antioxidant capabilities that are much stronger than those of vitamins $C$ and $E$ (Shahidi, Janitha and Wannasundara 1992; Pietta 1997; Amic et al. 2003). Evidence also showed that flavonoids can protect membrane lipids from oxidation induced damages by delaying or inhibiting the oxidation of lipids or other macromolecules by blocking the initiation or propagation process of oxidative chain reactions (Velioglu et al. 1998). The antioxidant activity of phenolic components are mainly due to their redox potentials, which can play crucial role in absorbing and neutralizing free radicals, by quenching the singlet and triplet oxygen radicals, or decomposing the peroxides (Osawa 1994). Many of the phyto-constituents of natural products possess significant antioxidant capacities that may be associated with lower incidence and lower mortality rates in cases of cancer in different human populations (Velioglu et al. 1998). In our study we also found the presence of flavonoids, tannin, terpanoid and alkaloid in the ethanolic extract of O.gratissimum which may be responsible for its ameliorative effects against oxidative stress induced DNA damage caused by sodium arsenite in O.cuniculus $L$.

Sinha et al. 2009, analyzed the oxidative stress induced DNA damage detected by the development of comet tailand reduction in Head DNA \%, as a result of exposure to arsenic and its recovery by Curcumin in human lymphocytes. In the present study we also observed a significant recovery of damaged DNA indicated by reduction in comet tail after treatment with Ocimum gratissimum $\mathrm{L}$. alcoholic leaf extract in O. cuniculus L.

Lee, Yang and Wang 2007, assessed sodium arsenite induced genotoxicity in human lymphoblastoid cells by using RAPD-PCR method.

In our study also the RAPD analysis exhibited characteristic alterations in the banding patterns indicating DNA damage in sodium arsenite treated lymphocyte cells of Oryctolagus cuniculus L. compared to Ocimum gratissimum ethanolic extract treated and control cells. These variations occurred in the number of DNA bands, their sizes and the loss of existing bands and the appearance of some new ones. Such kind of variations in the banding patterns revealed DNA polymorphisms. The amplification of DNA and its unique and non-unique banding patterns might occur due to the presence of base-pair sequences and their orientation in the genome that are complementary to the sequences of the primers used. 
The emergence of novel DNA bands may occur as a result of some oligonucleotide priming sites becoming accessible to primers due to point mutations, transpositions, breaks, large deletions or insertions, and/or homologous recombination which brings out structural changes in the DNA sequence (Atienzar and Jha 2006; Cansaran- Duman et al. 2015).

The loss of DNA bands may also be related to DNA damages due to single or double strand breaks, modified bases, appearance of basic sites, oxidized bases, formation of large DNA adducts, and DNAprotein cross links, and/or intricate chromosomal rearrangements (Atienzar and Jha 2006).

These changes in the attributable characters of DNA banding patterns found in the RAPD assay may occur due to the structural changes in the base pair sequences within the primer binding sites of the genomic DNA under the influence of oxidative and related genotoxic stress provoked by sodium arsenite during replication of DNA or gene expression (Kumar et al. 2009).

The gain or loss of RAPD bands may be linked to DNA damage, gene mutations, insertions or deletions of nitrogenous bases, nucleotide substitutions within the target sites and/or structural rearrangements, which may be induced by genotoxic sodium arsenite, influencing the primer sites and/or inter-priming lengths (Lal et al. 2011; Singh and Roy 2001).

Significant DNA polymorphism observed in RAPD pattern in the present study may be due to certain heritable changes in the nucleotide sequences of DNA samples of cells exposed to sodium arsenite. These changes may occurred in the coding and non-coding regions (Lal et al. 2011) or they might occurred due to structural changes in the genomic DNA that altered the length across two annealing sites and deletion of an existing site or due to changes during the course of gene expression (Dhakshanamoorthy, Selvaraj and Chidambaram 2011). This implies that insertion or deletion of the amplified regions of DNA and related alterations in the nitrogenous base sequences in turn leads to polymorphism in the RAPD profile significantly.

In our study, we observed that sodium arsenite increased the instability of DNA templates of cells, in a concentration-dependent manner. This result supports the conclusion that arsenic is a genotoxicant that have the potential to attack hotspots present in DNA. The number of stable bands increased as a function of time and dose. Arsenic might act as genotoxicant via generation of free radicals in course of metabolism of the toxins through electrophiles or nucleophiles reacting with DNA. These interactions might create changes in DNA sequences that ultimately resulting in the generation of new priming sites and/or disappearances of pre-existing priming sites for the RAPD primers. Thus, it gives different RAPD profiles for cells exposed to sodium arsenite (Bouhlel et al. 2010). Thus, DNA polymorphism analyses are suitable for the assessment of genetic variation patterns in response to heavy metal induced oxidative stress and related genotoxicity.

In our study the differences in antioxidant enzyme activity in control and sodium arsenite treated lymphocyte cells of $O$. cuniculus, formation of Comet tail and polymorphic DNA bands in RAPD analysis, indicated that Arsenic is responsible for development of oxidative stress in O.cuniculus that leads to DNA 
damage and it can be recovered by 0 . gratissimum leaf extract.In view of presence of various secondary metabolites as well as antioxidant vitamin (ascorbic acid) in 0 . gratissimum L., it can be inferred that these compounds found in the plant are responsible for the control of oxidative stress and DNA damage in the lymphocyte cells of $O$. cuniculus $L$., induced by arsenic.

Wijesinghe et al. 2011, reported the protective effect of methanol extracts of citrus juice plants on $\mathrm{H}_{2} \mathrm{O}_{2}$ mediated oxidative damage to DNA in Vero cells in terms of comet assay which exhibited strong inhibitory effects against $\mathrm{H}_{2} \mathrm{O}_{2}$ mediated DNA damage and exhibited recovery of the damaged DNA in a dose-dependent manner. Another similar study on oxidative stress induced DNA damage and recovery by applying plant extracts with antioxidant potential followed by its assessment by comet assay method (Sikder et al. 2013) indicates that many natural plant products and their extracts have antioxidant capabilities that endows them to protect the living cells and tissues from oxidative stress induced DNA damages and comet assay is a reliable tool for such type of assessments.

\section{References}

Agency for Toxic Substances and Disease Registry (ATSDR) (2005) Toxicological Profile for Arsenic. Agency for Toxic Substances and Diseases Registry U.S. http://www.atsdr.cdc.gov/toxprofiles/tp2.pdf.

Akinmoladun AC, Ibukun EO, Afor E, Obuotor EM, Farombi EO (2007) Phytochemical constituent and antioxidant activity of extract from the leaves of Ocimum gratissimum. Sci Res Essays 2(5):163-166.

Amic D, Davidovic-Amic D, Beslo D, Trinajstic N (2003) Structure-radicals scavenging activity relationship of flavonoids. Croat Chem Acta 76(1):55-61.

Anjorin ST, Ugwu NH (2011) Growth characteristics, phytochemicals and mineral composition of Ocimum gratissimumapplied with Albitbioproduct. ABJNA 2(4):693-697.

Atienzar FA, Jha AN (2006) The random amplified polymorphic DNA (RAPD) assay and related techniques applied to genotoxicity and carcinogenesis studies: a critical review. Mutat Res 613: 76-102.

Awah FM, Verla AW (2010) Antioxidant activity, nitric oxide scavenging activity and phenolic contents of Ocimum gratissimum leaf extract. J Med Plant Res 4(24):2479-2487.

Bergmeyer HV, Gowehu K, Grassel M (1974) Methods of Enzymatic Analysis Academic Press New York.

Bouhlel I, Limem I, Skandrani I, Nefatti A, Ghedira K, Dijoux-Franca MG, Leila CG (2010) Assessment of isorhamnetin 3-0-neohesperidoside from Acacia salicina: protective effects toward oxidation damage and genotoxicity induced by afl atoxin B1 and nifuroxazide. J Appl Toxicol 30:551-558.

Brindha P, Sasikala P, Purushothaman KK (1981) Pharmocognostic studies on Merugan kizhangu. Bull Med-Ethno Bot- Res 3:84-96. 
Cansaran-Duman D,Altunkaynak E, Aslan A, Büyük I, Aras S (2015) Application of molecular markers to detect DNA damage caused by environmental pollutants in lichen species. Genet Mol Res 14(2):46374650.

Chakraborti D, Mukherjee SC, Pati S, Sengupta MK, Rahman MM, Chowdhury UK, Lodh D, Chanda CR, Chakraborti AK, Basu GK (2003) Arsenic groundwater contamination in Middle Ganga Plain, Bihar, India: A Future Danger. Environ Health Perspect 111(9):1194-1201.

Chakraborti D, Sengupta MK, Rahman MM, Ahamed S, Chowdhury UK, Hossain MA, Mukherjee SC, Pati S, Saha KC, Dutta RN, Quamruzzaman Q (2004) Groundwater arsenic contamination and its health effects in the Ganga-Meghna-Brahmaputra Plain. J Environ Monit 6:75N-83N.

Choudhury GB, Behera M, Jena PK, Tripathy SK (2011) Pharmacognostical and phytochemical investigation of various Tulsi plants available in South Eastern Odisha. Int J Res Pharm Biomed Sci 2(2): 605-610.

Corsini E, AstiL, Viviani B, Marinovich M., Galli CL (1999) Sodium arsenate induces overproduction of interleukin-1alpha in murine keratinocytes: role of mitochondria. J Investig Dermatol 113:760-5.

Dhakshanamoorthy D, Selvaraj R, Chidambaram ALA (2011) Induced mutagenesis in Jatropha curcas L. using gamma rays and detection of DNA polymorphism through RAPD marker. C R Biol 334:24-30.

Dubey NK, Tiwari TN, Mandin D, Andriamboavonjy H, Chaumont JP (2000) Antifungal properties of Ocimum gratissimum essential oil (ethyl cinnamate chemotype). Fitoterapia 7(15):567-569.

Gambell MV, Liu X, Ahsan H, Pilsner R, Ilieveski V, Slavkovich V, Parvez F, Levy D, Factor-Litvak P, Grazino $\mathrm{JH}$ (2005) Folate, homocysteine and arsenic metabolism in arsenic exposed individuals in Bangladesh. Environ Health Perspect 113:1683-1686.

Harborne JB, Williams CA (2000) Advances in flavonoid research since 1992. Phytochemistry 55:481-504.

Hei TK, Liu SX, Waldren C (1998) Mutagenecity of arsenic in mammalian cells: Role of reactive oxygen species. PNAS 95:8103-8105.

Holets FB, Ueda-Nakamura T, Filho BPD, Cortez DAG, Morgado-Diaz JA, Nakamura CV (2003) Effect of essential oil of Ocimum gratissimum on the Trypanosomatid Herpetomonas samuelpessoai. Acta Protonzool 42:269-276.

Inskeep WP, Macur RE, Hamamura N, Warelow TP, Ward SA, Santini JM (2007) Detection, diversity, and expression of aerobic bacterial arsenite oxidase genes. Environ Microbiol 9:934-943.

Islam FS, Gault AG, Boothman C, Polya DA, Charnok JM, Chatterjee D, Lloyd JR (2004) Role of metal reducing bacteria in arsenic release from Bengal delta sediments. Nature 430:68-71. 
Kitchin KT, Ahmad S (2003) Oxidative stress as a possible mode of action for arsenic carcinogenesis. Toxicol Lett 137: 3-5.

Kumar A (2009) Antioxidant effect of Adiantum capillus veneris Linn. on human lymphocyte: an in vitro study. J Cell Tissue Res 9(2):1899-1902.

Kumar P, Gupta VK, Misra AK, Modi DR, Pandey BK (2009) Potential of molecular markers in plant biotechnology. Plant Omics 2(4):141-162.

Lal S, Mistry KN, Shah SD, Thaker R, ShahSD, Vaidya PB (2011) Genetic diversity assessment in nine cultivars of Catharanthus roseus from Central Gujarat (India) through RAPD, ISSR and SSR markers. J Biol Res 1(8):667-675.

Lee YC, Yang VC, Wang TS (2007) Use of RAPD to detect sodium arsenite-induced DNA damage in human lymphoblastoid cells. Toxicol 239:108-115.

Liu SX, Athar M, Lippai I, Waldren C, Hei TK (2001) Induction of oxyradicals by arsenic: implication of mechanism of genotoxicity. PNAS 98:1643-1646.

Manna P, SinhaM, Sil PC (2008) Protection of arsenic induced testicular oxidative stress by arjunolic acid. Redox Rep 13:67-70.

Misra HP, Fridovich I (1972) The role of superoxide anion in the autoxidation of epinephrine and a simple assay for superoxide dismutase. J Biol Chem 247(10):3170-3175.

Moron MS, Depierre JW, Mannervik B, (1979) Activity of glutathione, glutathione reductase and glutathione S-transferase activities in rat lung and liver. Biochim Biophys Acta 582:67-78.

Niwa U, Doi Y, Kato Y, Osawa T (2001) Antioxidant properties of phenolic antioxidants isolated from corn steep liquor. J Agric Food Chem 49:177- 182.

Obioma NJOKUU, Elijah JP, Emmanuel OC, Victor AV, Juliana UO (2011) Antioxidant Properties of Ocimum gratissimum(Scent Leaf). N Y Sci J 4(5): 98:103.

Ohkawa H, Ohishi N., Yagi K (1979) Assay for lipid peroxides in animal tissues by thiobarbituric acid reaction. Ann. Clin Biochem 95:351-358.

Okigbo RN, Ogbonnanya OU (2006) Antifungal effects of two tropical plants extracts Ocimum gratissimum and Afromaomum melegueta on post harvest yam Discorea spp rot. Afr J Biotechnol 5(9):727-731.

Onajobi FD (1986) Smooth muscle contracting lipidic soluble principle in chromatographic functions of Ocimum gratissimum. J Ethnopharmacol 18:3-11. 
Osawa T (1994) Novel natural antioxidants for utilization in food and biological systems. In: Uritani I, Garcia VV, Mendoza EM (eds) Postharvest biochemistry of plant food-materials in the tropics. Tokyo, Japan: Japan Scientific Societies Press pp.241-251.

Pandey PK, Khare RN, Sharma S, Sar SK, Pandey M, Binayke P, 1999. Arsenicosis and deteriorating groundwater quality: Unfolding crisis in Central East India Region. Curr Sci77:686-693.

Pietta PG (1997) Flavonoids in medicinal plants. In: Rice-Evans CA, Packer L (eds) Flavonoids in health and disease, New York: Dekker pp61-110.

Preston RJ, San Sebastian RJ., McFee AF (1987) The in vitro human lymphocyte assay for assessing clastogenicity of chemical agents. Mutat Res 189:175-183.

Rekha PS, Kuttan G, Kuttan R (2001) Antioxidant activity of brahma rasayana. Indian J Exp Biol 39:447452.

Romero FJ, Bosch-Morell M, Romero MJ, Jareno EJ, Romero B, Marin N, Roma J (1998) Lipid peroxidation products and antioxidants in human disease. Environ Health Perspect 106:1229. Maxwell SRJ, (1995) Prospects for use of antioxidant therapies. Drugs 49:345-361.

Rotruck JT,Pope AL, Ganthe HE, Swanson AB, Hafeman DG, Hoekstra WG (1973) Selenium: biochemical role as a component of glutathione peroxidase. Science 179:588-590.

Santra A, Chowdhury A, Ghatak S, Biswas A, Dhali GK (2007) Arsenic induces apoptosis in mouse liver is mitochondria dependent and is abrogated by N-acetylcysteine. Toxicol Appl Pharmacol 220:146-55.

Scartezzini P, Speroni E (2000) Review on some plants of Indian traditional medicine with antioxidant activity. J Ethnopharmacol 1:23-43.

Shahidi F, Janitha PK, Wanasundara PD (1992) Phenolic antioxidants. Crit Rev Food Sci Nutr 32(1):67103.

Shi H, Shi X, Liu KJ, (2004) Oxidative mechanism of arsenic toxicity and carcinogencity.. Mol Cell Biochem 255(1-2):67-78.

Sikder K, Sinha M, Das N, Das DK, Datta S, Dey S (2013) Moringa oleifera leaf extract prevents in vitro oxidative DNA damage. Asian J Pharm Clin Res 6(2):159-164.

Singh KP, Roy D (2001) Identification of novel breast tumor-specific mutation(s) in the q11.2 region of chromosome 17 by RAPD/AP-PCR fingerprinting. Gene 269:33-43.

Singh NP, McCoy MT, Tice RR, Schneider EL (1988) A simple technique for quantification of low activity of DNA damage in individual cells. Exp Cell Res 75:184-191. 
Sinha D, Mukherjee, S, Roy S, Bhattacharya, RK, Roy M (2009) Modulation of arsenic induced genotoxicity by curcumin in human lymphocytes. J Environ Chem Ecotoxicol 1(1):1-11.

Sofowora A (1993) Medicinal Plants and Traditional Medicine in West Africa. $2^{\text {nd }}$ ed, John Wiley and Sons, New York ISBN 9782462195.

Sulistiarini DL (1999) Ocimum gratissimum L.In: Oyen PA, NguyenED.(eds) Plant Resources of South-East Asia, vol. 19, Essential oils Plants (Prosea Foundation, Bogor, Indonesia) pp140.

Trease GE,Evans WC (1985) Pharmacognosy 12th ed English Language Book Society, Bailliere Tindall, London.

VeliogluYS, Mazza G, Gao L, Oomah BD (1998) Antioxidant activity and total phenolics in selected fruits, vegetables, and grain products. Journal of Agricultural and Food Chemistry 46:4113-4117.

Vogt BL, Rossman, TG (2001) Effects of arsenic on p53, p21 and cyclin D expression in normal human fibroblasts - a possible mechanism of arsenite's comutagenicity. Mutat Res 478:159.

Wijesinghe WAJP, Senevirathne M, Oh Myung-CheolJeon You-Jin (2011) Protective effect of methanol extracts of citrus juice plants prepared by far-infrared radiation drying on $\mathrm{H}_{2} \mathrm{O}_{2}$ mediated oxidative damage in Vero cells. Nutr Res Pract 5(5):389-395.

Williams JG, KubelikAR, Livak KJ,Rafalski JA (1990) DNA polymorphisms amplified by arbitrary primers are useful as genetic markers. Nucleic Acids Res 18:6531-6535.

World Health Organization (WHO) (2001) Arsenic in drinking-water. Geneva, World Health Organization (WHO Fact Sheet No. 210; http://www.who.int/ mediacentre/ factsheets/fs210/en/print.html).

World Health Organization (WHO) (2011) Arsenic in Drinking-water Background document for development of WHO Guidelines for Drinking-water Quality. World Health Organization 20 Avenue Appia, 1211 Geneva 27, Switzerland.

\section{Tables}


Tablel Showing Phytoconstituents of O.gratissimum L, O. sanctum.L. and $O$. basilicum $L$.

\begin{tabular}{|l|c|c|c|c|c|c|}
\hline Plants $\longrightarrow$ & \multicolumn{2}{c|}{ Ocimum gratissimum } & \multicolumn{2}{c|}{ Ocimum sanctum } & \multicolumn{2}{c|}{ Ocimum basilicum } \\
\hline Solvents $\longrightarrow$ & E & $\mathbf{C}$ & $\mathbf{E}$ & $\mathbf{C}$ & $\mathbf{E}$ & $\mathbf{C}$ \\
\hline Cardiac Glycoside & - & + & + & - & + & - \\
\hline Steroids & + & - & + & + & + & - \\
\hline Flavonoids & + & - & - & - & - & - \\
\hline Saponins & - & + & - & + & - & - \\
\hline Tanins & + & - & - & - & - & - \\
\hline Terpenoids & + & + & + & - & + & + \\
\hline Alkaloids & + & + & - & + & + & + \\
\hline
\end{tabular}

\section{E - Ethanol; C - Chloroform; $\quad(-)$ absent; $(+)$ present}

Table 2 Showing variation in number of polymorphic bands in RAPD analysis of O.cuniculus after chronic exposure of sodium arsenite and recovery by $O$. gratissimum L.

\begin{tabular}{|c|c|c|c|c|c|}
\hline S.No. & $\begin{array}{l}\text { Primers } \\
\text { (Operon) }\end{array}$ & Sequence & $\begin{array}{l}\text { Control Set of } \\
\text { Test Animal }\end{array}$ & $\begin{array}{l}\text { Treated with } \\
\text { Sodium Arsenite }\end{array}$ & $\begin{array}{l}\text { Treated with Ocimum } \\
\text { gratissimum L. leaf extract }\end{array}$ \\
\hline 1 & OPA01 & CAGGCCCTTC & 5 & 9 & 4 \\
\hline 2 & OPA03 & AGTCAGCCAC & 3 & 10 & 3 \\
\hline 3 & OPC06 & GATGACCGCC & 4 & 6 & 4 \\
\hline 4 & OPA04 & AATCGGGCTG & 3 & 6 & 4 \\
\hline 5 & OPA07 & GAAACGGGTG & 2 & 5 & 2 \\
\hline 6 & OPC04 & CCGCATCTAC & 1 & 3 & 2 \\
\hline \multicolumn{3}{|c|}{ Total Number of Bands } & 18 & 39 & 19 \\
\hline \multicolumn{3}{|c|}{$\begin{array}{l}\text { Average [Number of polymorphic } \\
\text { bands per primer] }\end{array}$} & 3.0 & 6.5 & 3.16 \\
\hline
\end{tabular}

\section{Declarations}

\section{Funding}

This work was supported by the Chhattisgarh Council of Science \& Technology, Chhattisgarh, India under Grant [ Endt No. 2154/CCOST/MRP/2013, Raipur, Dt. 22.03.13.].

\section{Conflict of interest}

The authors have declared that there are no potential conflicts of interest with respect to the research, authorship, and /or publication of the article to this journal. 
All available data have been included in manuscript.

\section{Code Availability}

Not Applicable.

\section{Authors' Contributions}

Anil Kumar: Conceptualization and Supervision, Nikhil Mishra: Statistical analysis and interpretation, Seema Tripathi: Manuscript preparation.

\section{Ethical approval}

Test animals, Oryctolagus cuniculus L (Rabbit) was selected and maintained in Laboratory following approval of the Institutional Ethics Committee (Ref. No.IEC/GVYTPGAC/02/DURG, dated 28/09/2012) of Government V.Y.T.PG. Autonomous College, Durg, Chhattisgarh, India.

\section{Consent to Participants}

Not Applicable.

\section{Consent for Publication}

All authors have agreed for publication of present manuscript in the journal, "Environmental Science and Pollution Research, Special Issue-MF-EIHAN-2021", and further declare that the findings related to manuscript have not published elsewhere and the manuscript is not currently under consideration by another journal.

\section{Figures}




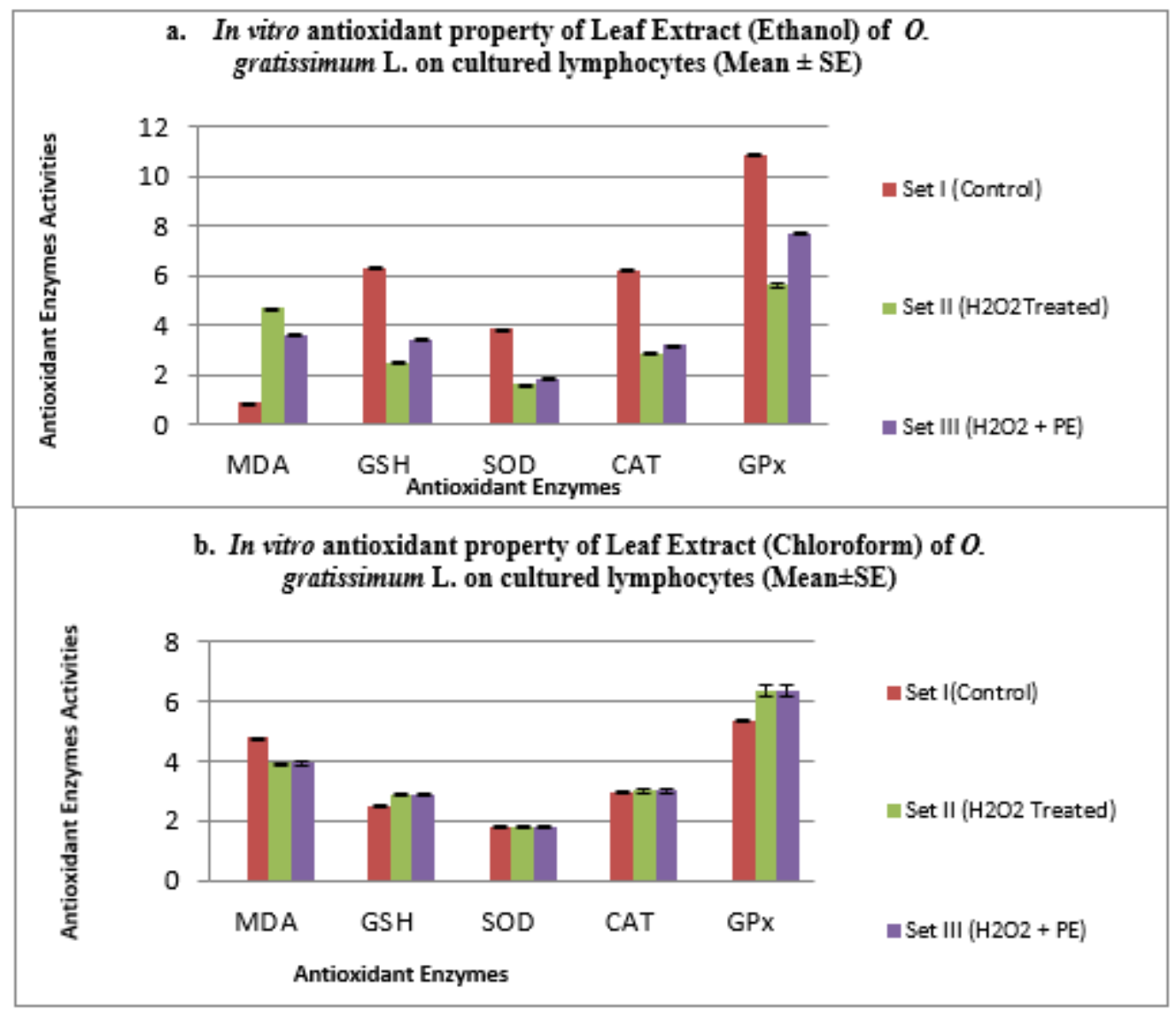

Figure 1

In vitro Enzymatic Assay - Graph showing assessment of In vitro antioxidant property of Leaf Extract of O. gratissimum L. (a. Ethanol; b. Chloroform) on cultured lymphocytes.

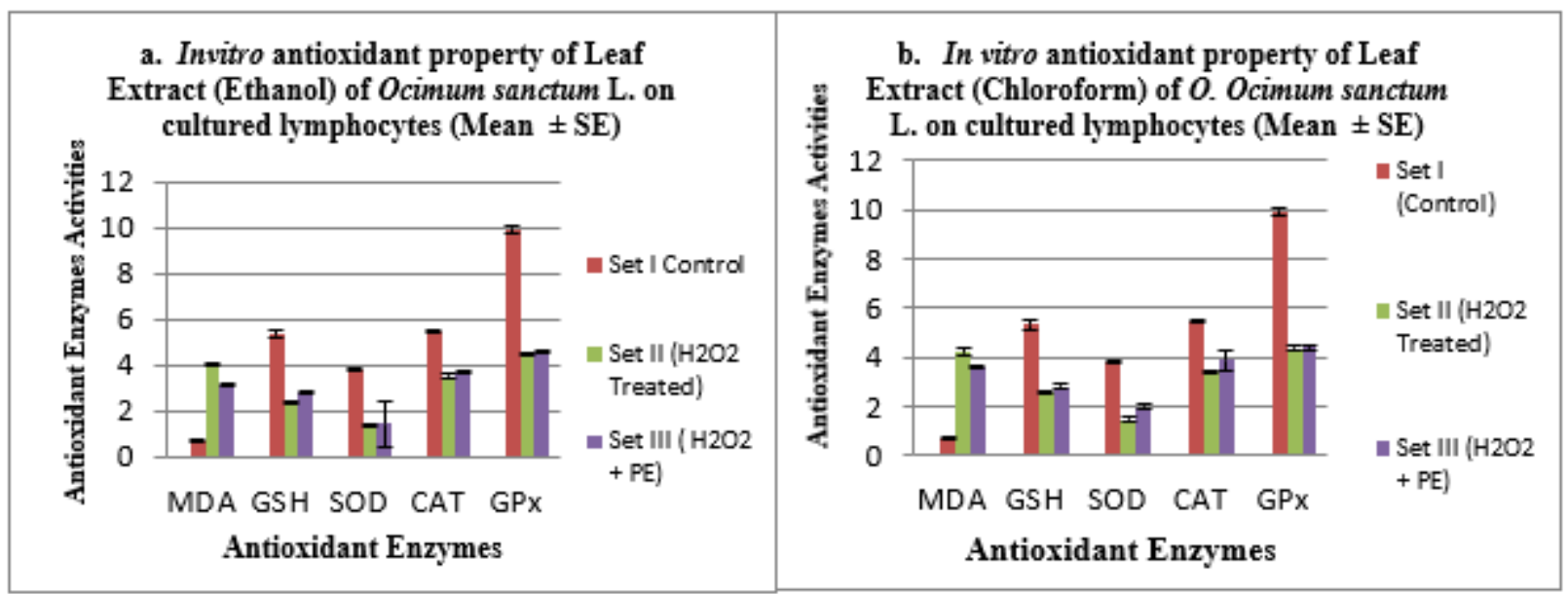

Figure 2

In vitro Enzymatic Assay - Graphs showing assessment of Invitro antioxidant property of Leaf Extract of O. sanctum L. (a. Ethanol; b. Chloroform) on cultured lymphocytes. 


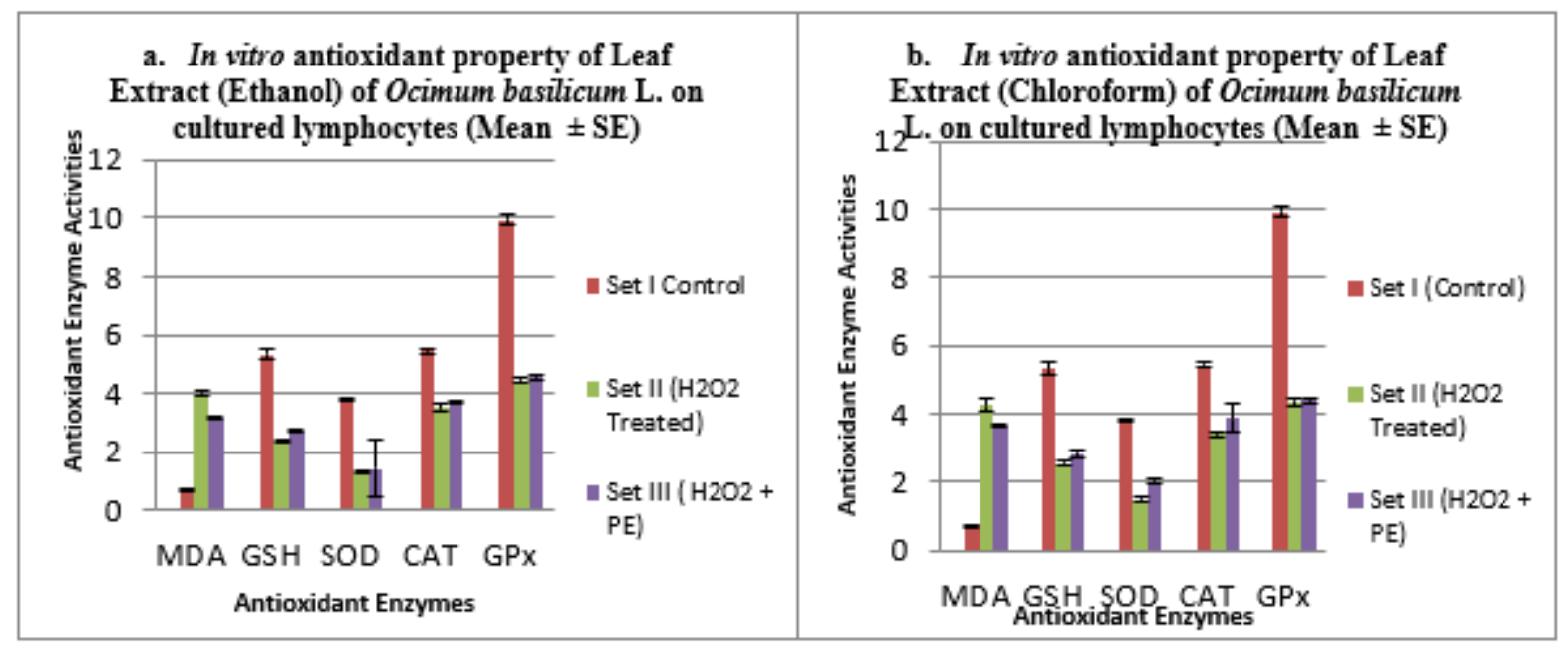

\section{Figure 3}

In vitro Enzymatic Assay - Graph showing assessment of Invitro antioxidant property of Leaf Extract of Ocimum basilicum L. (a. Ethanol; b. Chloroform) on cultured lymphocytes.

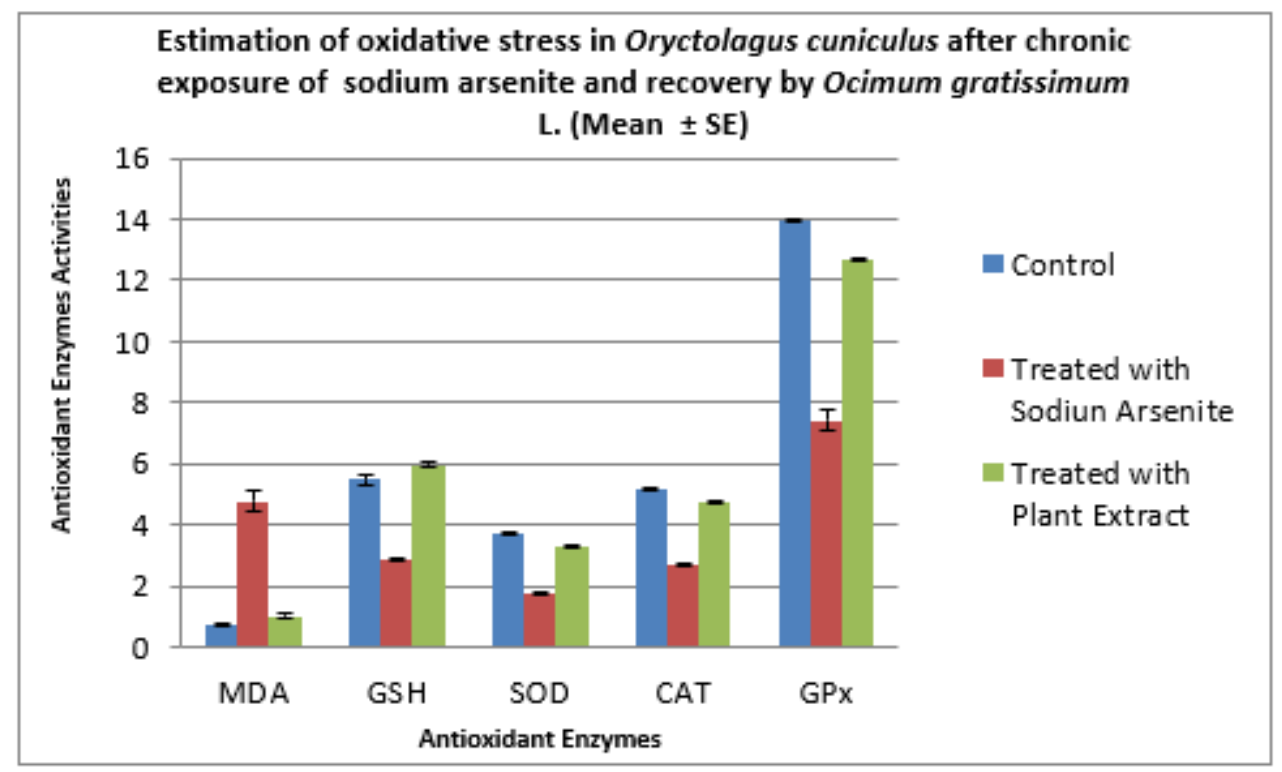

\section{Figure 4}

In vivo estimation of oxidative stress in 0 . cuniculus after chronic exposure of sodium arsenite considering MDA, GSH, SOD, CAT and GPx and recovery by O. gratissimum L. Leaf Extract (Ethanol).

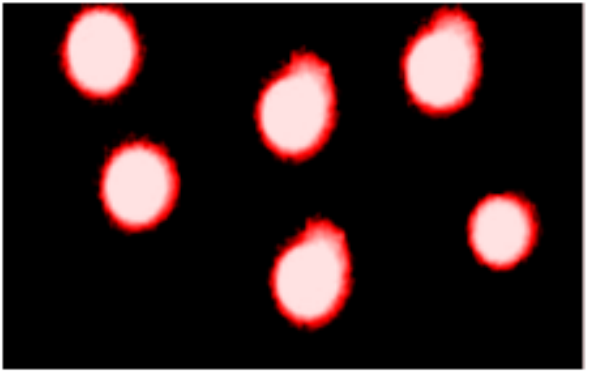




\section{Figure 5}

Showing intact comets of DNA in Control animals.

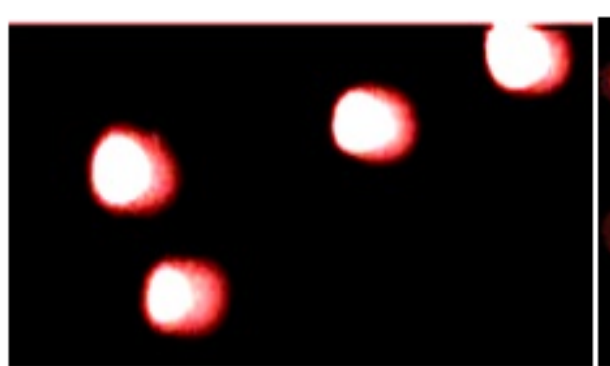

(a)

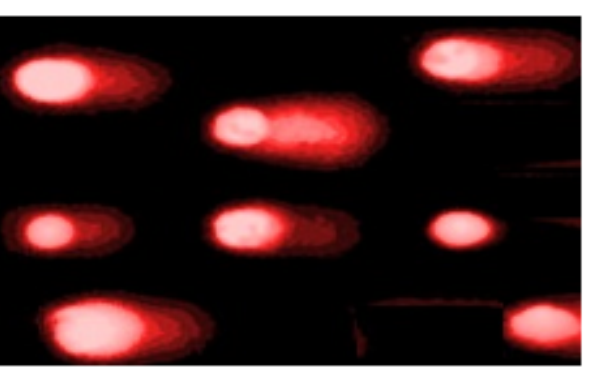

(b)

\section{Figure 6}

Showing Comet tail after Chronic exposure of Sodium Arsenite (a) After 3 months (b) After 6 months of Treatment

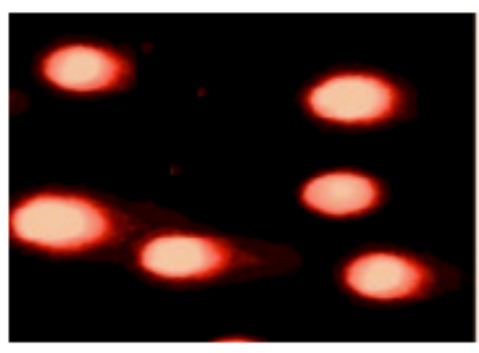

\section{Figure 7}

Showing reduced Comet tail after treatment of leaf extract of $\mathrm{O}$. gratissimum L. for one month. 


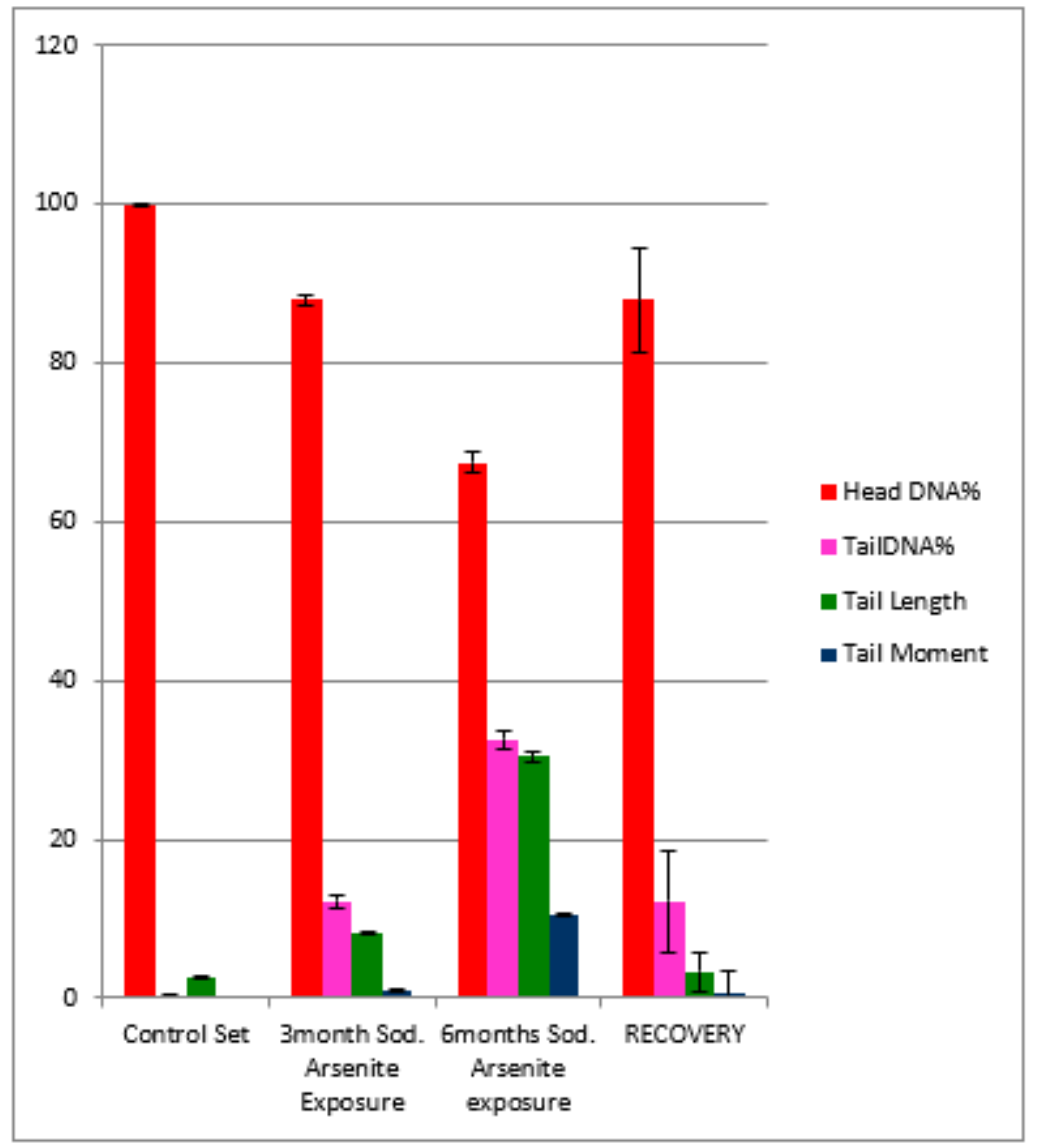

Figure 8

Mean and Standard Error values of Comet Assay in different sets of test animals (Oryctolagus cuniculus L.)

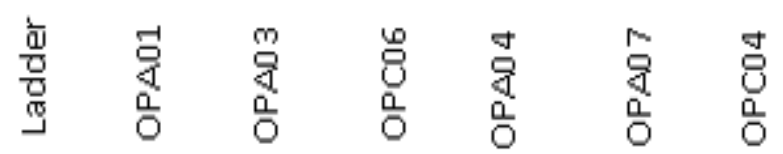

900

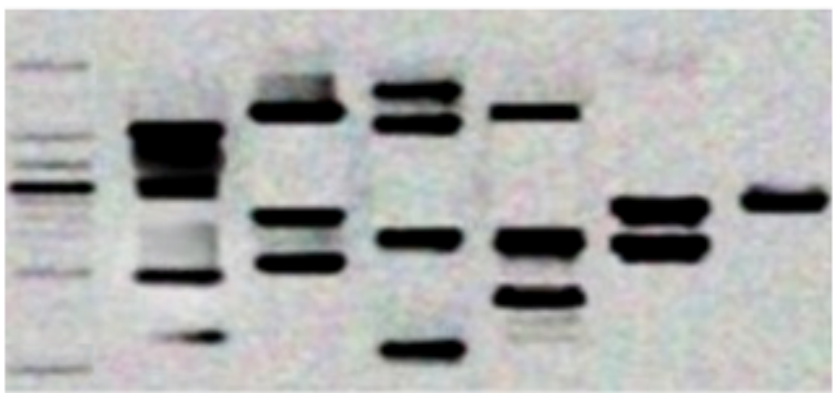

Figure 9

Showing RAPD-PCR bands in control set of test animal O. cuniculus L. (Molecular weight marker -1000bp) Lane1: marker (100bp each band); Lane 2: 720, 542,408,291,160; Lane 3: 774,450,332; Lane4: 823,742, 395,142; Lane 5: 774, 395, 228; Lane 6: 471, 381; Lane7: 485 (in base pairs as analyzed by Gel documentation system from Lark). 


\section{1 ำ}

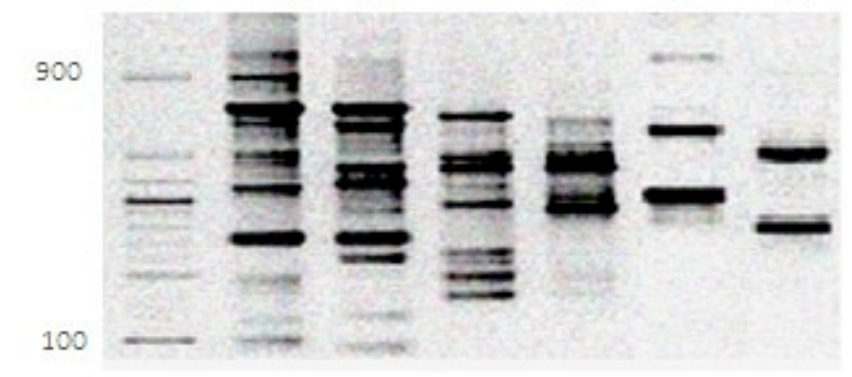

\section{Figure 10}

Showing Polymorphic DNA band amplified by different primers after chronic exposure of Sodium arsenite in O. cuiculus L. (Lane1:marker; Lane 2 : 932, 900, 799, 723, 597, 388, 234, 132 ; 100 Lane3:858,799, 771, 688, 632, 506, 388, 2975, 93; Lane4: 785,709,527,318,232,207; Lane5: 778, 709, 520, 232, 219, 129 ; Lane6: $864,771,678,576,485$; Lane7: $826,730,437$ (in base pairs as analyzed by Gel documentation system from Lark).
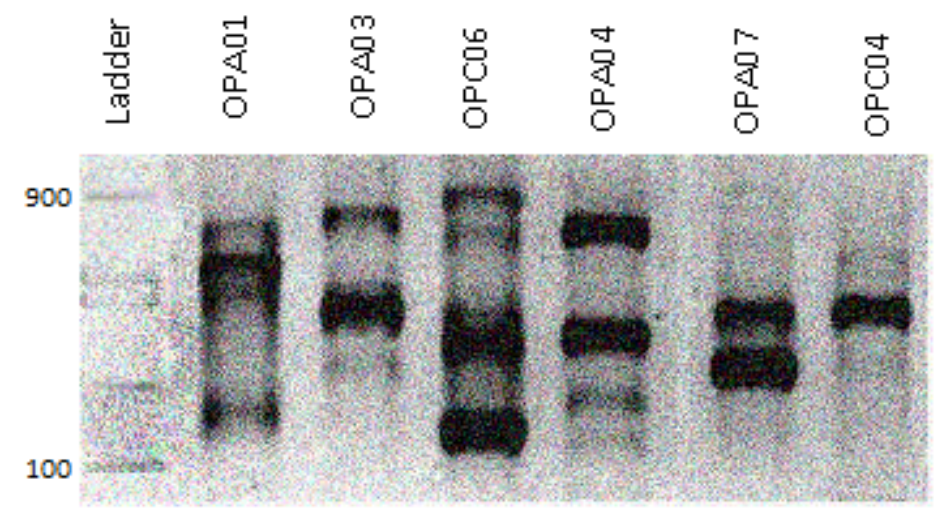

\section{Figure 11}

Showing Polymorphic DNA band amplified by different primers after chronic exposure of Sodium arsenite in O.cuiculus treatment with Ethanolic leaf extract of O. gratissimum L. (Lane1: marker; Lane2: 717,626,548,246; Lane3:753,500,338; Lane4:832,696,366,218; Lane5: 700,408,274,197; Lane6: 464,338; Lane7: 633,485(in base pairs as analyzed by Gel documentation system from Lark). 